\title{
PERSEPSI PEMILIK DAN PENGETAHUAN AKUNTANSI PELAKU USAHA MIKRO KECIL DAN MENENGAH (UMKM) ATAS PENYUSUNAN LAPORAN KEUANGAN
}

\author{
Yuli Setyawati \\ Sigit Hermawan \\ Fakultas Ekonomi dan Bisnis, Universitas Muhammadiyah Sidoarjo, Indonesia \\ Jl. Majapahit 666 B, Sidoarjo \\ Email : sigithermawan@umsida.ac.id
}

\begin{abstract}
In many studied, the contribution of micro small and medium enterprises (UMKM) to economi has been proven, but on the other hand the perpetrators of this scale are still facing many problems, one of them is in managing finance, especially in the use of accounting knoeledge in the preparation of financial statements. The perception of managers is strongly suspected to be one of the key issued. This study aims and medium enterprises (MSMEs) for te preparation of financial statements.

This research used qualitative research method with a interpretive approach. The analysis instrument of this is triangulation of data. Data collection come from interview, observation, and documentation of informants who key of this study. The result of analysis showed that micro business actors in Krian and Pasuruan region have already made financial report of bookkeeping record although they are simple, and their accounting knowledge is quite simple according to their education level. However, small and medium enterprises (MSMEs) are still difficult to prepare their financial statements properly.
\end{abstract}

Keyword : Perceptions of owners of small and medium enterprises, Knowledge of Accounting, and Financial Statements.

Abstrak - Dibanyak penelitian, konstibusi pelaku usaha mikro kecil dan menengah (UMKM) terhadap perekonomian memang telah terbukti, namun disisi lain pelaku skala ini juga masih banyak menghadapi masalah, salah satunya adalah dalam mengelola keuangan, terutama dalam penggunaan pengetahuan akuntansi dalam penyusunan laporan keuangan. Persepsi pengelola diduga kuat menjadi salah satu kunci permasalahn ini. Penelitian ini bertujuan untuk mengetahui persepsi dari pemilik dan pengetahuan akuntansi pelaku usaha mikro kecil dan menengah (UMKM) atas penyusunan laporan keuangan.

Tujuan penelitian ini adalah untuk mengetahui persepsi pemilik dan pengetahuan akuntansi pelaku UMKM atas penyusunan laporan keuangan. Penelitian ini menggunakan metode penelitian kualitatif dengan pendekatan interpretif. Analisis data yang digunakan adalah triangulasi data dengan pengumpulan data yang berasal dari wawancara, observasi, dan dokumentasi terhadap informan kunci penelitian. Hasil analisis menunjukkan bahwa pelaku usaha mikro di wilayah Krian dan Pasuruan sebenarnya sudah membuat laporan keuangan atau catatan pembukuan walaupun terbilang sederhana, dan pengetahuan akuntansi yang mereka miliki tergolong sederhana sesuai dengan tingkat pendidikan mereka. Namun demikian para pelaku usaha mikro kecil dan menengah (UMKM) masih dirasa kesulitan untuk menyusun laporan keuangan mereka sebagaimana mestinya.

Kata Kunci : Persepsi pemilik UMKM, Pengetahuan Akuntansi dan Laporan Keuangan

\section{PENDAHULUAN}

UMKM atau biasa disebut dengan Usaha Mikro Kecil dan Menengah adalah sebuah usaha yang bergerak di berbagai bidang usaha diantaranya, usaha perdagangan, usaha pertanian, usaha industri, usaha jasa dan lain-lain. Di Indonesia, UMKM merupakan salah satu cara yang efektif dalam mengurangi angka kemiskinan dan pengangguran. Dari data statistik yang dilakukan, UMKM mewakili jumlah kelompok usaha terbesar. UMKM merupakan kumpulan dari berbagai pelaku ekonomi terbesar dalam perekonomian di Indonesia serta menjadi faktor pertumbuhan ekonomi pasca krisis ekonomi. Selain menjadi kontribusi besar dalam pembangunan nasional, UMKM juga dapat menjadi peluang kerja yang cukup besar bagi tenaga kerja di Indonesia yang tentunya membutuhkan pekerjaan di sulitnya mencari pekerjaan di jaman globalisasi sekarang ini. Oleh karena itu dibutuhkan kesadaran kita untuk mengembangkan unit-unit UMKM 
agar terciptanya kesejahteraan masyarakat. UMKM juga menjadi perhatian lebih pemerintah untuk lebih lagi mengembangkan unit-uni UMKM. Karena keberhasilan UMKM mempunyai manfaat yang sangat besar khususnya untuk perekonomian Indonesia, membuat masyarakat pelaku UMKM lebih mandiri, membuat masyarakat lebih aktif dan kreatif dalam berpikir ide-ide terbaru untuk pengembangan usahanya.

Namun dibalik itu semua, terdapat kendala atau tantangan yang dihadapi pelaku UMKM yaitu terkait dengan pengeolahan dana dan penyusunan laporan keuangannya karena pengolahan dana yang baik akan menjadi faktor penting dalam keberhasilan UMKM itu sendiri. Menurut Suhairi (2004) berpendapat bahwa kelemahan UMKM dalam penyusunan laporan keuangan disebabkan rendahnya pendidikan, kurangnya pemahamam terhadap Standar Akuntansi Keuangan (SAK), dan pelatihan penyusunan laporan keuangan. Selain itu, hasil penelitian ini sesaui dengan hasil penelitian yang dilakukan oleh Jati et.al., (2009) bahwa pelaksanaan pembukuan akuntansi untuk menghasilkan laporan keuangan merupakan hal yang masih sulit bagi UMKM. Keterbatasan pengetahuan pembukuan akuntansi, rumitnya proses akuntansi, dan anggapan bahwa laporan keuangan bukanlah hal yang penting bagi UMKM

Berdasarkan permasalahan diatas, perlu adanya upaya perbaikan pengembangan UMKM diantaranya membantu permodalan dengan kredit khusus yang mempermudah syarat-syarat untuk tidak memberatkan bagi pelaku UMKM. Membantu peningkatan permodalan baik dari sektor financial formal atau sektor financial informal. Perlindungan usaha, baik usaha tradisional yang tergolong ekonomi rendah maupun usaha tinggi harus mendapat perlindungan dari pemerintah baik dari Undang-Undang ataupun peraturan pemerintah. Pengembangan kemitraan yang saling membantu UMKM baik dari pangsa pasar dalam negeri maupun pangsa pasar luar negeri. Selain itu pelatihan pemerintah bagi UMKM baik dari aspek kewirausahaan, manajemen, administrasi dan pengetahuan tentang akuntansi atas pembukuan keuntungan dalam laporan keuangan.

Selain itu, menurut penelitian yang dilakukan oleh Deddy Kurniawanysah (2016) menyatakan bahwa sulit untuk melakukan pencatatan akuntansi dengan segala keterbatasan yang dimiliki. Kebutuhan dalam penyelenggaraan catatan akuntansi dianggap hanya membuang waktu dan biaya. Sedangkan penelitian yang dilakukan oleh Elisabeth, Ika dan Chandra (2012) menunjukkan bahwa sebagian besar UMKM di Salatiga sudah melakukan pencatatan atas penjualan, pembelian, persediaan, biaya gaji dan biaya lainnya. Sedangkan pelaporan yang dibuat meliputi laporan penjualan, pembelian, persediaan dan penggajian. Kendala yang menghambat UMKM dalam penerapan akuntansi antara lain adalah latar belakang pendidikan, belum pernah mengikuti pelatihan akuntansi dan belum ada kebutuhan terhadap penerapan akuntansi. Tujuan penelitian ini adalah untuk mengetahui persepsi pengetahuan akuntansi yang dimiliki pelaku usaha mikro kecil dan menengah (UMKM) atas penyusunan laporan keuangan.

\section{KAJIAN PUSTAKA}

\section{Persepsi}

Menurut Robbins (2008 : 175) persepsi (perception) adalah proses dimana suatu individu menafsirkan dan mengatur kesan-kesan secara sensoris mereka dengan tujuan arti di lingkungan mereka. Namun terkadang apa yang mereka terima dapat berbeda dari realita sebenarnya. Perbedaan tersebut sering timbul walapun sebenarnya tidak perlu ada.

\section{Pengetahuan Akuntansi}

Pengetahuan akuntansi merupakan persepsi yang jelas dipandang sebagai kebenaran, fakta, atau kewajiban atas informasi mengenai proses pencatatan, pengelompokan, mengihktisaran kejadian-kejadian ekonomi yang disusun dalam bentuk logis dan teratur dengan maksud menyajikan informasi keuangan yang dibutuhkan untuk pengambilan keputusan (Timotius dan Belkaoiu, 2000).

\section{Usaha Mikro Kecil dan Menengah (UMKM)}

Menurut Undang-Undang No.20 Tahun 2008 tentang UMKM, dapat didenifisikan Usaha Kecil dan Menengah yaitu, Usaha Mikro adalah usaha aktif milik perorangan dan/atau badan usaha perorangan yang memenuhi kriteria usaha mikro (aset maksimal 50 juta dan omset 300 juta) sebagaimana yang sudah diatur dalam Undang-Undang. Usaha Kecil adalah usaha ekonomi aktif yang dikelola perorangan atau badan usaha yang bukan merupakan anak perusahaan dan bukan cabang anak perusahaan yang dikuasai, dimiliki atau menjadi bagian dari usaha menengah atau usaha besar yang sudah memenuhi kriteria sebagaimana yang sudah diatur dalam Undang-Undang ini. Sedangkan Usaha Menengah adalah usaha ekonomi aktif yang berdiri sendiri, yang dijalankan oleh perorangan atau badan usaha yang bukan merupakan anak perusahaan atau cabang perusahaan yang dikuasai, dimiliki atau menjadi usaha bagian baik secara langsung maupun 
tidak langsung dengan usaha besar atau mikro dengan jumlah kekayaan bersih atau hasil dari penjualan secara tahunan sebagaimana yang sudah diatur dalam UndangUndang ini.

\section{Laporan Keuangan}

Menurut IAI (Ikatan Akuntan Indonesia) berdasarkan PSAK 1 paragraf 10 (2012), laporan keuangan adalah suatu penyajian secara tersrtuktur dari posisi keuangan dan kinerja keuangan entitas. Laporan keuangan menyajikan informasi mengenai entitas meliputi aset, liabilitas, ekuitas, pendapatan dan beban yang termasuk keuntungan dan kerugian, kontribusi, serta arus kas. Dengan adanya suatu entitas yang disajikan maka dapat digunakan untuk pembuatan keputusan ekonomi.

\section{METODE PENELITIAN}

Penelitian ini menggunakan penelitian kualitatif, menurut Hermawan dan Amirullah (2016:191), Penelitian kualitatif adalah proses penelitian yang didasarkan pada fakta sosial dan alamiah (naturalistik) dengan peneliti sebagai instrumen kunci, data deskriptif, tidak berdasarkan analisis statistik, dan dilaporakn secara naratif. Penelitian ini dilakukan di dua tempat pelaku usaha mikro yaitu Krian dan Pasuruan.

Fokus penelitian adalah untuk mengetahui bagaimana persepsi atau pandangan para pelaku usaha mikro. Persepsi yang dimaksud adalah pandangan atau pendapat para pelaku usaha mikro dikaitkan dengan pengetahuan akuntansi yang digunakan untuk pengelolaan usahanya, pengetahuan akuntansi untuk menyusun laporan keuangan, dan bagaimana bentuk laporan yang dibuat oleh para pelaku usaha tersebut.

Unit analisis penelitian ini adalah pendapat informan tentang persepsi terhadap usaha mikro kecil dan menengah (UMKM), bagaimana penggunaan pengetahuan akuntansi para pelaku dalam operasional usahanya, bagaimana pelaku usaha mikro dalam menyusun laporan keuangan, bagaimana bentuk laporan keuangan para pelaku usaha mikro, serta kendala yang dihadapi pelaku usaha mikro dalam penyusunan laporan keuangan. Informan kunci dalam penelitian ini adalah pelaku usaha mikro, Dinas Koperasi dan Usaha Mikro, serta Dosen Ekonomi dan Bisnis Universitas Muhammadiyah Sidoarjo. Penentuan informan dilakukan dengan judgement sample (Marshall, 1996).

Penelitian ini menggunakan in depth interview dan pendokumentasian untuk pengumpulan data (Marshall, 2006). In depth interview dilakukan dengan semua informan kunci baik di satu tempat ke tempat informan yang lain. Pendokumentasian dilakukan dengan mengambil data yang revelan dari informan kunci, dan sejumlah literatur dari perpustakaan dan internet. Keabsahan data dalam penelitian ini menggunakan triangulasi.

Proses analisis data dilakukan selama pengumpulan data. Proses seperti ini lazim digunakan dalam penelitian kualitatif sebagaimana rekomendasi Miles dan Huberman (1984). Adapun tahapan analisis yang dilakukan adalah data collection, data reduction, data display, dan conclusion. Pada tahapan data collection, semua data masuk apa adanya sesuai dengn hasil wawancara dan dokumentasi. Namun dalam melakukan proses pengumpulan data, peneliti selalu mendasarkan pada panduan wawancara. Penyusunan panduan-panduan tersebut didasarkan pada rumusan masalah, tujuan dan fokus penelitian, teori pendukung, serta hasil riset terdahulu. Pada proses data collection juga dilakukan keabsahan data utamanya untuk uji kredibilitas (credibility) dengan cara triangulasi. Misalnya hasil wawancara satu informan di member check ke informan yang lain. Demikian juga dengan hasil wawancara di-cross check dengan data dokumentasi, teori pendukung, atau juga dengan cara meminta tanggapan dari Dinas Koperasi dan Usaha Mikro yang lebih paham akan topik yang dibahas. Dengan cara yang demikian dapat lebih dijamin data yang diperoleh memiliki tingkat keabsahan yang tinggi. Proses data reduction dilakukan selama penelitian berlangsung. Cara yang dilakukan dengan menyeleksi data yang terkait dengan tema atau topik penelitian yang telah ditentukan. Apabila data tidak terkait maka data direduksi atau dibuang. Data dengan tema atau konsep yang sama akan diberi kode (proses coding). Hasil dari data reduction akan dibuat data display dengan menyusun rangkaian wawancara ke dalam matriks display hasil penelitian. Berdasarkan matriks inilah peneliti dapat mengambil petikan-petikan wawancara yang penting untuk ditampilkan ke dalam pembahasan hasil penelitian dan juga untuk menunjukkan kealamiahan penelitian kualitatif. Tahap terakhir dari analisis data adalah conclusion. Pada tahap ini peneliti mengambil simpulan, pada awalnya sangat tentatif, tidak jelas, dan diragukan. Akan tetapi dengan bertambahnya data, simpulan akan lebih lengkap. 
Tabel 1

Informan Kunci Penelitian

\begin{tabular}{|c|c|c|c|}
\hline NO & $\begin{array}{c}\text { KETERANG } \\
\text { AN }\end{array}$ & $\begin{array}{c}\text { INFORMA } \\
\mathbf{N} \\
\end{array}$ & JABATAN \\
\hline 1 & $\begin{array}{c}\text { Home } \\
\text { Industri } \\
\text { Tahu }\end{array}$ & H.Sumbaji & Pemilik \\
\hline 2 & $\begin{array}{c}\text { Home } \\
\text { Industri } \\
\text { Tahu }\end{array}$ & H. Gufron & Pemilik \\
\hline 3 & $\begin{array}{c}\text { Home } \\
\text { Industri } \\
\text { Bakpia }\end{array}$ & $\begin{array}{l}\text { Ika Puji } \\
\text { Astutik }\end{array}$ & Pemilik \\
\hline 4 & $\begin{array}{c}\text { Home } \\
\text { Industri } \\
\text { Bakpia }\end{array}$ & Kurniawan & Pemilik \\
\hline 5 & $\begin{array}{c}\text { Dosen } \\
\text { Universitas } \\
\text { Muhammadi }\end{array}$ & $\begin{array}{c}\text { Nihlatul } \\
\text { Qudus SN, } \\
\text { SE., MM }\end{array}$ & Dosen \\
\hline
\end{tabular}

konsep atau pola yang sama hasil dari proses analisis data.

Tabel 2

Proses Coding, Konsep atau Pola-pola yang sama

Coding Tema atau Konsep

1 Penerapan pengetahuan akuntansi dalam UMKM.

2 Pengetahuan akuntansi untuk penyusunan laporan keuangan pelaku UMKM.

3 Bentuk-bentuk laporan keuangan pelaku UMKM.

\begin{tabular}{ll}
\hline 4 & $\begin{array}{l}\text { Mengetahui laba/rugi dalam laporan } \\
\text { keuangan pelaku UMKM. }\end{array}$
\end{tabular}

5 Persepsi pelaku UMKM terhadap laporan keuangan SAK ETAP.

$6 \quad$ Kendala-kendala yang dihadapi oleh pelaku usaha mikro (UMKM) dalam penyusunan laporan keuangan.

\section{Sumber: Data Display Hasil Coding dan Data Reduction}

\section{Penerapan Pengetahuan Akuntansi dalam UMKM}

Menurut pendapat informan selaku pelaku usaha mikro bahwa pengetahuan akuntansi itu memang sangat penting khususnya untuk mengelola dan operasional usaha. Dan mereka mengatakan bahwa menerapkan pengetahuan akuntansi untuk usahanya walaupun terbilang sederhana dan tidak

\begin{tabular}{|c|c|c|c|}
\hline \multicolumn{4}{|c|}{ yah Sidoarjo } \\
\hline 6 & $\begin{array}{c}\text { Dinas } \\
\text { Koperasi dan } \\
\text { UMKM } \\
\text { Sidoarjo }\end{array}$ & $\begin{array}{c}\text { Muhammad } \\
\text { Mahfud }\end{array}$ & $\begin{array}{c}\text { Kasi Bina } \\
\text { Usaha } \\
\text { Mikro }\end{array}$ \\
\hline Sumb & r: Peneliti & & \\
\hline
\end{tabular}

Analisis data dilakukan dengan menggabungkan data-data yang diperoleh dari indepth interview dan pendokumentasian. Dengan menggunakan empat triangulasi sebagai uji kredibilitas data dan data reduction dengan menggunakan coding, serta didukung oleh peneliti sebagai instrumen penelitian, peneliti mampu menghasilkan tema atau konsep yang sama. Berikut disajikan dalam secara sistematis akuntansi pada umumnya atau pengetahuan akuntansi yang berada di bangku perkuliahan. Karena memang terkadang masalah pendidikan menjadi salah satu masalah perbedaan tersebut. Tetapi terkadang tingkat pendidikan tidak menjadi patokan akan sebuah usaha selagi pelakupelaku UMKM tersebut selalu mengupdate pengetahuan akuntansi dari jaman ke jaman. Dan penerapan penetahuan akuntaansi memang dibutuhkan sebuah pembinaan, pelatihan yang membuat para pelaku usaha mikro tersebut akan terbiasa menerapkan pengetahuan akuntansi dalam usahany. Berikut pernyataan informan MM:

"Untuk pengembangannya kita selalu dan terus menerus melakukan pembinaan. Permbinaannya tentunya, jika terkait legalitas tetap kita bina legalitasnya yang menyangkut ijin, kedua pembinaan terkait produk nanti ada pembelajaran tentang kemasan produk, ada foto produk, terkait pemasaran offlineonline ini kita akan terus mengembangkan dan itu kita akan buat secara bergilir. Yang kita bina pasti bukan itu-itu saja, karena dengan jumlah pelaku UMKM yang sangat banyak tidak mungkin kita mengadakan dalam sekali acara. Jadi yang jelas kita akan terus membantu selagi kita difasilitasi anggaran. Karena Pemerintah Sidoarjo sudah berkomitmen untuk itu karena Sidoarjo sudah menjadi kota UMKM. Seperti dengan adanya Klinik Koperasi dan Usaha Mikro ini dapat dijadikan tempat sharing permasalahn mereka yang perlu didiskusikan supaya kita dapat mencarikan solusi, jadi keberadaan Klinik ini sangat membantu. Walaupun sementara belum ada anggaran di Dinas Koperasi dan Usaha Mikro ini, teman-teman di Klinik ini dapat membantu promosi dari pihak ketiha seperti UPD-UPD, Kantor Pajak, Kantor BPJS dan lainnya. 
Ini membantu sekali jadi pelaku-pelaku kita bina sesuai anggaran Dinas Koperasi dan Usaha Mikro bisa diikutsertakan pihak-pihak yang lain. Karena Klinik ini manfaatnya luar biasa. Jadi kita tidak mengandalkan itu-itu saja. Dengan keberadaan Klinik dan aplikasi yang sudah kami buat, beberapa pengunjung baik dari luar daerah seperti Sulawesi, Kalimantan dating kemari untuk membuktikan bahwa Sidoarjo kota UMKM" (Bapak Muhammad Mahfud wawancara tanggal 12 Maret 2018, 10:50 WIB).

Seperti pada hasil studi oleh Inn et al (2015) yang menjelaskan bahwa pemerintah dalam menjalankan tugasnya harus benar-benar memposisikan diri sebagai pelatih dan pendidik, bukan hanya sekedar menjalankan tugas dan pekerjaannya. Oleh karena itu penting bagi pemerintah khususnya Dinas Koperasi dan Usaha Mikro Sidaoarjo berupaya memberikan sebuah pelatihan pengelolaan keuangan, pemahaman akan pentingnya penerapan akuntansi dalam usaha mereka. Jika adanya pembinaan dan pelatihan secara berkelanjutan, maka para pelaku-pelaku UMKM tersebut akan terbiasa menerapkan pengetahuan akuntansi dalam usahanya. Karena memang para pelaku UMKM terkadang beranggapan bahwa penerapan pengetahuan akuntansi yang tinggi hanya diterapkan pada perusahaan/usaha yang besar. Tapi ternyata mau usaha kecil ataupun besar seorang pelaku usaha sangat memerlukan yang namanya pengetahuan akuntansi jika ingin usahanya terus berkembang.

Hasil penelitian ini sesuai dengan penelitian Nursetto (2004) Terkait dengan permasalahan keuangan dan pembukuan, para pengusaha UMKM pada umumnya mereka tidak menguasai dan tidak mempraktekkan sistem keuangan yang memadai. Pada umumnya usaha kecil tidak atau belum memiliki pengetahuan dan kemampuan dalam mengelola catatan akuntansi secara ketat dan berdisiplin dengan pembukuan yang teratur, baik dalam bentuk harian, mingguan, bulanan, dan seterusnya, sehingga banyak diantara mereka yang belum memahami pentingnya pencatatan dan pembukuan bagi kelangsungan usaha.

Tabel 3

Hasil Penelitian dan Uji Kredibilitas (Triangulasi Sumber dan Triangulasi Teori-Riset Pendukung)

\begin{tabular}{ccc}
\hline $\begin{array}{c}\text { Penerapan } \\
\text { Pengetahuan } \\
\text { Akuntansi }\end{array}$ & Operasionalisasi & $\begin{array}{c}\text { Uji } \\
\text { Credibility }\end{array}$ \\
\hline -Aktor atau pihak & -pelaku usaha mikro & -informan \\
yang penerapkan & kecil dan menengah & MM, \\
pengetahuan & (UMKM) & HS,HG,IP,K \\
akuntansi & -manajer & -Inn et al \\
& -investor & $(2015)$ \\
\hline
\end{tabular}

\begin{tabular}{cc}
\hline -pemerintah & -Nursetto \\
-kreditor & $(2004)$ \\
\hline Sumber: Data Display dan Data Reduction
\end{tabular}

\section{Pengetahuan Akuntansi untuk Penyusunan Laporan Keuangan Pelaku UMKM}

Hal mendasar yang perlu dikenal terlebih dahulu oleh para calon pengusaha yang ingin mendirikan usahanya sendiri adalah pengetahuan akuntansinya. Pengetahuan akuntansi yang dimaksud adalah pengetahuan untuk menyusun laporan keuangan. Laporan keuangan memang menjadi hal penting dalam perusahaan baik perusahaan kecil atau perusahaan besar sekalipun. Karena dengan melihat laporan keuangan yang kita buat dapat menganalisis bagaimana keadaan perusahaan kita. Apakah mengalami kenaikan atau penuruanan. Dalam penyusunan laporan tersebut memang dibutuhkan pengetahuan akuntansi untuk menyusunnya. Entah dilakukan sendiri oleh pemilik usaha atau dilakukan oleh orang lain yang mungkin lebih ahli dibidang tersebut. Tetapi akan lebih baiknya jika memang pemilik tidak seberapa memiliki pengetahuan akuntansi maka dapat menggunakan jasa orang lain untuk membantu menyusun laporan keuangan usahanya. Dengan adanya pelaporan yang disusun entah setiap bulan akan tahunan akan membawa manfaat dikemudian hari. Contohnya untuk peminjaman dana di Bank atau Koperasi. Pihak Bank dan Koperasi akan memproses peminjaman tersebut jika pelaku atau pemilik usaha tersebut memperlihatkan laporan keuangannya. Walaupun di catat dalam bentuk sederhana yang penting ada pencatatan keuangan yang dilakukan. Dan kebanyakan para pelaku usaha mikro pengandalkan pengetahuan akuntansi yang terbilang sederhana yang mereka tahu untuk menyusun laporan keuangan mereka. Menurut informan penelitian, pengetahuan akuntansi yang mereka miliki untuk menyusun laporan keuangan usahnya terbilang cukup sederkana. Dengan pemahaman debet dan kredit mereka dapat menyusun laporan keuanganya. Berikut pernyataan informan HG:

"Pengetahuan akuntansi yang saya miliki sekedar mencatat pembukuan biasa secara kredit atau tunai. Ya cuma semacam pengeluaran dan pemasukan saja dengan mengumpulkan bukti-bukti berupa notanota itu. Yang penting kegiatan hitung mengitung dan catat mencatat sudah termasuk ilmu akuntansi kan mbak" (Bapak H. Gufron wawancara tanggal 7 Maret 2018, 10:00 WIB).

Penelitian ini juga memiliki kesamaan dengan penelitian yang dilakukan oleh Kurniawati, Nugroho dan Arifin (2012) dengan hasil penelitian 
menunjukkan bahwa catatan yang digunakan adalah pencatatan pembelian, pembelian, persedian, kas masuk, kas keluar, biaya-biaya dan gaji. Sedangkan untuk pelaporan akuntansinya hanya digunakan untuk kepentingan pengelolahan usaha. Laporan yang dibuat misalnya laporan penjualan, laporan pembelian, laporan persediaan, dan laporan gaji. Dan untuk kendala penerapan akuntansinya disebabkan karena kurangnya tingkat pendidikan pelaku usaha, belum mengikuti pelatihan akuntansi sebelumnya.

Hal tersebut didukung oleh penelitian Dian (2009) yang menyimpulkan bahwa pengetahuan akuntansi berpengaruh signifikan terhadap kualitas laporan keuangan, menurut peneliti semakin tinggi tingkat pengetahuan akuntansi, maka semakin baik pula kualitas laporan keuangan yang dihasilkannya. Hasil penelitian tersebut sejalan dengan teori yang dinyatakan Roviyantie (2011), menyebutkan bahwa laporan keuangan merupakan sebuah produk yang dihasilkan oleh bidang atau disiplin ilmu akuntansi. Oleh karena itu, dibutuhkan sumber daya manusia yang kompeten untuk menghasilkan sebuah laporan keuangan yang berkualitas. Dapat juga dikatakan bahwa untuk dapat menghasilkan laporan keuangan yang berkualitas maka kualitas orang-orang yang melaksanakan tugas dalam menyusun laporan keuangan harus menjadi perhatian utama yaitu para pegawai yang terlibat dalam aktivitas tersebut harus mengerti dan memahami bagaimana proses dan pelaksanaan akuntansi itu dijalankan dengan berpedoman pada ketentuan yang berlaku, oleh karena itu pengetahuan akan akuntansi seorang pemilik perusahaan disarankan ditingkatkan agar penyusunan pelaporan keuangan berdasarkan standar-standar akuntansi.

Tabel 4

Hasil Penelitian dan Uji Credibility (Triangulasi Sumber dan Triangulasi Teori-Riset Pendukung)

\begin{tabular}{ccc}
\hline $\begin{array}{c}\text { Pengetahuan } \\
\text { akuntansi dan } \\
\text { Laporan } \\
\text { keuangan }\end{array}$ & Operasionalisasi & $\begin{array}{c}\text { Uji } \\
\text { Credibility }\end{array}$ \\
& & \\
-Pemahaman & \\
akunatansi & pengetahuan & -Informan \\
untuk & Debet, Kredit. & -Kurniawati, \\
penyusunan & -Pengetahuan & Nugroho dan \\
laporan & akuntansi untuk & Arifin (2012) \\
keuangan & laporan keuangan & - Dian (2009) \\
& berupa pencatatan & -Roviyantie \\
& pembelian, kas & $(2011)$ \\
& masuk, kas keluar, & \\
\hline
\end{tabular}

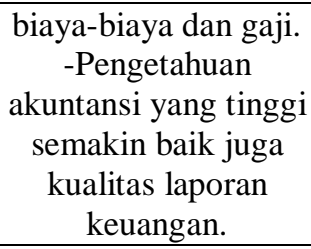

\section{Sumber: Data Display dan Data Reduction}

\section{Bentuk-bentuk Laporan Keuangan Pelaku UMKM}

Menurut para informan, mereka belum mengetahaui berbagai bentuk laporan keuangan pada dasarnya yang sesuai dengan standar akuntansi yang terdiri dari neraca, laba/rugi, arus kas, posisi keuangan dan catatan atas laporan keuangan. Yang mereka ketahui bahwa laporan keuangan hanya berupa satu jenis yang biasa mereka sebut dengan pembukuan. Sebagian dari para informan menyebutkan terlalu sulit untuk memilah-milah laporan keuangannya dalam lima bentuk laporan keuangan tersebut. Jangankan memisah-misahkan, bahkan bentuk laporan keuangan mereka juga belum tentu benar. Para pelaku usaha mikro mengatakan bahwa kegiatan untuk memisahkan laporan keuangan sesuai dengan kebutuhannya tersebut dapat dilakukan oleh perusahaan yang sudah terbilang besar. Padahal walaupun tidak semua dipisahkan ke dalam lima komponen dasar akuntansi tersebut, setidaknya laporan keuangan bisa dipisahkan menurut pengeluarannya. Seperti buku kas, buku biaya, buku penjualan, buku pembelian, buku hutang, buku piutang, laporan laba/rugi. Namun nyatanya di lapangan, para pelaku usaha mikro hanya membuat laporan keuangan atau pembukuan usaha mereka dalam bentuk yang sederhana yang bisa mereka pahami.

Selanjutnya bentuk laporan keuangan yang dibuat oleh para pelaku usaha mikro contohnya adalah laporan pemesanan produksi, jadi para pelaku usaha mikro akan menbuat laporan tersebut apabila mereka menerima pemesanan dalam jumlah yang sedikit lebih banyak dari biasanya. Laporan tersebut terdiri dari semua biaya-biaya pembelian bahan baku, biaya-biaya beban, sampai jumlah produksi dan harga jual pasaran. Seperti pernyataan informan IP berikut :

"Waduh, saya tidak memakai laporan. Cuma ya saya tulis seumpama ini ada pemesanan tanggal berapa sebanyak sekian, dengan harga sekian, dan untuk pembelian bahan baku produksi sekian habis pembelian bahan baku sekian, untuk biaya operasional sekian. Ya pokoknya secara sederhana mbak, tidak seperti perusahaan-perusahaan itu" (Ibu Ika Puji wawancara tanggal 18 Maret 2018, 11:00 WIB). 
Mungkin itu memang laporan sederhana yang dibuat sendiri oleh pelaku usaha mikro dalam kegiatan pengelolaan keuangannya. Kegiatan tersebut sebenarnya jauh dari kata pelaporan yang sistematis secara akuntansi, namun kembali ke diri masingmasing pelaku usaha, seberapa tahu mereka tentang pengetahuan akuntansi dalam penyusunan laporan keuanganya. Seperti yang sudah dijelaskan diatas, bahwa semakin tinggi pendidikan dan pengetahuan akuntansi pelaku usaha mikro, maka semakin berkualitas laporan keuangan yang dihasilkan. Hal tersebut sejalan dengan penelitian yang dilakukan oleh Dian (2009) yang menyimpulkan bahwa pengetahuan akuntansi berpengaruh signifikan terhadap kualitas laporan keuangan, menurut peneliti semakin tinggi tingkat pengetahuan akuntansi, maka semakin baik pula kualitas laporan keuangan yang dihasilkannya.

Dengan demikian, apabila dikaitkan dengan hasil penelitian sebelumnya, bahwa penelitian ini sesuai dengan hasil penelitian (Jati et al., 2009) yang mengatakan bahwa kebanyakan dari UMKM hanya mencatat jumlah uang yang diterima dan dikeluarkan, jumlah barang yang dibeli dan dijual, dan jumlah piutang atau utang. Namun pembukuan itu tidak dengan format yang diinginkan oleh pihak perbankan. Mempekerjakan seseorang secara khusus untuk melakukan pembukuan akuntansi dan penyusunan laporan keuangan masih menjadi hal yang kurang realistis bagi banyak UMKM sebab akan menambah pengeluaran untuk membayar gaji dari tenaga akuntansi tersebut. Artinya memang para pelaku usaha mikro membuat bentuk tersendiri laporan keuangannya yang mereka pahami dan sesuai dengan pengetahuan akuntansi yang mereka miliki.

Tabel 5

Hasil Penelitian dan Uji Credibility (Triangulasi Sumber dan Triangulasi Teori-Riset Pendukung)

\begin{tabular}{ccc}
\hline $\begin{array}{c}\text { Bentuk- } \\
\text { bentuk } \\
\text { laporan } \\
\text { Pelaku }\end{array}$ & Operasionalisasi & $\begin{array}{c}\text { Uji } \\
\text { Credibility }\end{array}$ \\
UMKM & & \\
\hline -Bentuk & - Laporan terdiri dari & \\
laporan & semua biaya-biaya & -informan \\
keuangan & pembelian bahan baku, & HS, HG,IP,K \\
yang & biaya-biaya beban, & - Dian (2009) \\
dibuat oleh & sampai jumlah produksi & - Jati et al., \\
pelaku & dan harga jual pasaran. & 2009 \\
usaha & -laporan order & \\
mikro & (pemesanan) & \\
\hline Sumber: Data Display dan Data Reduction &
\end{tabular}

Sumber: Data Display dan Data Reduction

\section{Mengetahui Laba/Rugi Dalam Laporan Keuangan Pelaku UMKM}

Menurut informan dalam penelitian ini cara mereka dalam mengetahui laba/rugi dalam usaha mereka adalah cukup mudah. Yaitu dengan cara berapa uang uang mereka terima dari hasil produksi yang dikeluarkan. Jika hasil pengeluaran produksi lebih banyak dari hasil penjualan yang diterima maka mereka mengatakan itu rugi, dan sebaliknya jika hasil penjualan yang diterima dari hasil pengeluarannya maka mereka dikatakan laba. Namun hasil tersebut mereka katakana belum dikurangin dengan bebanbeban yang harus dikeluarkan dalam berlangsungnya proses produksi. Namun begitulah cara mereka untuk mengetahui laba/rugi usahanya. Seperti pernyataan yang diberikan oleh informan HS:

"Ya kalau rugi pasti dilihat dari hasil pengeluaran kita disamakan dengan penjualan itu. Kalau pengeluaran lebih banyak ya jelas rugi saya, begitupun sebaliknya. Lalu rugi lagi kalau harga kedelai yang tinggi, jelas kadang saya rugi disitu kalau penjualannya tidak bisa mengimbangi" (Bapak H.Sumbaji wawancara tanggal 7 Maret 2018, 12:30 WIB).

Menurut SAK ETAP (2009), informasi yang disajikan di dalam laporan laba rugi minimal mencakup beberapa pos, yaitu pendapatan, beban keuangan, bagian laba atau rugi dari investasi yang menggunakan metode ekuitas, bebas pajak, dan laba atau rugi neto. Dalam laba/rugi ini kita dapat mencapat berapa pendapatan yang kita terima sesuai apa yang kita keluarkan melalui beban-beban dalam produksi tersebut sehingga kita dapat mendapat hasil bersih tersebut. Dari selisih jumlah pendapatan dan jumlah biaya tersebut dapat disebut laba atau rugi. Jika jumlah pendapatan lebih besar dari jumlah biaya, perusahaan dikatakan laba. Sebaliknya, bila jumlah pendapatan lebih kecil dari jumlah biaya, perusahaan dikatakan rugi.

Menurut informan lain dalam penelitian ini menyebutkan bahwa mereka bisa dikatakan untung atau laba apabila jumlah pemesanan yang didapatkan oleh para pelaku usaha mikro lebih banyak dari biasanya, contohnya pada musim hajatan. Para pelaku usaha mikro akan kebanjiran order. Dan mereka dikatakan merugi apabila terdapat retur dari hasil penjualan biasa mereka. Pernyataan seperti ini disampaikan oleh informan IP :

"Kalau untuk mengetahui untung ataupun rugi ya dari retur itu. Kalau ada retur ya pasti rugi kalau 
tidak ya pas lah yang penting modal kembali. Kalau ada yang tidak laku atau basi kan otomatis dibuang dan itu ya saya sedikit rugi. Juga tergantung musim orderan saja mbak. Kalau musim hajatan pasti orderan banyak pendapatan juga banyak" (Ibu Ika Puji wawancara tanggal 18 Maret 2018, 11:00 WIB).

Mengetahui laba atau rugi usaha sangatlah penting, agar mengetahui bagaimana posisi usaha saat ini. Apakah berada diatas dan mengalami keuntungan atau sebaliknya mengalami penurunan dan kerugian. Dan salah satu untuk mengetahui laba atau rugi dengan melihat laporan laba/rugi. Namun untuk para pelaku usaha mikro cara mengetahui laporan laba/rugi mereka memiliki pandangan sendiri-sendiri. Ada yang dengan cara melihat dari hasil penjualan mereka, dari banyak tidaknya orderan yang mereka terima hingga barang kembali (retur) namun hal tersebut belum dikurangi dengan beban-beban sehingga belum bisa dikatakan pendapatan bersih. Namun yang menjadi persepsi para pelaku usaha mikro adalah, yang terpenting mereka untung/laba dari usaha yang mereka geluti. Penelitian ini didukung dengan hasil penelitian yang dilakukan oleh Pinasti (2001) yang menunjukkan bahwa Para pelaku UMKM merasa terlalu direpotkan dengan penyelenggaraan catatan akuntansi tersebut dan menganggap bahwa yang penting adalah mereka mendapatkan laba tanpa direpoti dengan penyelenggaraan akuntansi.

Tabel 6

Hasil Penelitian dan Uji Credibility (Triangulasi Sumber dan Triangulasi Teori-Riset Pendukung)

\begin{tabular}{|c|c|c|}
\hline $\begin{array}{c}\text { Laba / Rugi } \\
\text { dalam } \\
\text { Laporan } \\
\text { Keuangan } \\
\text { UMKM }\end{array}$ & Operasionalisasi & $\begin{array}{c}\text { Uji } \\
\text { Credibility }\end{array}$ \\
\hline $\begin{array}{l}\text {-Mengetahui } \\
\text { laba/rugi } \\
\text { dalam laporan } \\
\text { keuangan } \\
\text { UMKM }\end{array}$ & $\begin{array}{c}\text {-Mengetahuinya dari } \\
\text { jumlah orderan } \\
\text { (Pemesanan yang } \\
\text { diterima) } \\
\text {-Terdapat retur dari } \\
\text { hasil penjualan } \\
\text { - mencakup beberapa } \\
\text { pos, yaitu pendapatan, } \\
\text { beban keuangan, } \\
\text { bagian laba atau rugi } \\
\text { dari investasi yang } \\
\text { menggunakan metode } \\
\text { ekuitas, bebas pajak, } \\
\text { dan laba atau rugi neto }\end{array}$ & $\begin{array}{c}\text {-informan } \\
\text { HS, HG, IP, } \\
\text { K } \\
\text { - Pinasti } \\
\text { (2001) } \\
\text {-SAK ETAP } \\
\text { (2009) } \\
\text { - Pinasti } \\
\text { (2001) }\end{array}$ \\
\hline
\end{tabular}

Sumber: Data Display dan Data Reduction

\section{Persepsi Pelaku UMKM Terhadap Laporan Keuangan SAK ETAP}

Menurut informan dalam penelitian ini mengenai Standar Akuntansi Keuangan Entitas Tanpa Akuntabilitas Publik (SAK ETAP) adalah salah satu Standar Akuntansi yang penggunaanya ditujukan untuk entitas usaha yang tidak memiliki akuntabilitas publik, seperti entitas usaha mikro, kecil dan menengah (UMKM). Namun pada kenyataannya bahwa para pelaku usaha mikro tersebut tidak mengetahui bahkan belum mendengar sekalipun tetang SAK ETAP. Jangankan untuk sekedar mendengar, untuk melihat bentuk SAK ETAP seberta komponenkomponennya pun mereka belum sama sekali. Sehingga standar tersebut menjadi sesuatu yang awam bagi mereka. Untuk itu dari pihak Pemerintah khususnya Dinas Koperasi dan Usaha Mikro juga masih belum mengetahui semua laporan keuangan para pelaku usaha mikro, apakah mereka membuat laporan keuangannya, apakah laporan keuangan mereka selama ini sudah benar apa belum, apalagi apakah mereka sudah membuatnya sesuai dengan standar akuntansi yang ada. Karena dari pihak Dinas Koperasi dan Usaha Mikro juga beranggapan kalau selama ini para pelaku usaha mikro tersebut menyimpan hasil penjualan mereka dengan cara mencatatnya atau hanya diangan-angan dalam ingatan mereka sehingga dari Dinas Koperasi dan Usaha Mikro sepakat untuk membuat sebuah acara pelatihan dan pembinaan untuk para pelaku ini sebagai bentuk turun tangannya pemerintah dalam membantu para pelaku usaha mikro. Berikut penyataan yang diberikan informan MM:

"Yang jelas saya optimis bahwa sebagai bahan awal kajian kita untuk kedepannya, kan sudah saya sampaikan tadi bahwa ini adalah acara perdana kita. Jadi yang menjadi ide kreatif saudara kami sepakat untuk terus berkesinambungan atau berkelanjutan untuk berinovasi apa yang menjadi bahan kekurangan walaupun hal keuangan ataupun modal, bentuk laporan keuangan pelaku UMKM itu seperti apa kan kita juga belum tau, entah yang baku, sistematis, dan seterusnya yang layak, yang akurat, namun berhubung ini event perdana, kami juga ingin melihat apa yang sudah dibuat, bagaimana cara mereka selama ini menyimpan hasil penjualan mereka, apa ditulis di pembukuan ataupun hanya diangan-angan mereka kan kita tidak tahu.

Maka dari itu, tema saya untuk kegiatan perdana ini adalah "Laporan Keuangan Sederhana”. Jadi kita ingin mengetahui laporan sederhana mereka, karena 
ini kan mikro. Kalau laporan keuangan menengah akan beda lagi begitupun yang usaha besar. Karena masih awalan pelatihan jadi kami melakukan secara sederhana terlebih dahulu. Namun kita tetap terus melakukan secara berkesinambungan atau untunguntung sampai pada Standar Akuntansi yang anda bilang tadi” (Bapak Muhammad Mahfud wawancara tanggal 12 Maret 2018, 10:50 WIB).

Kaitannya dengan SAK ETAP yang sebenarnya mempermudah para pelaku usaha mikro tersebut untuk memperoleh kredit di perbankan. Namun itu semua menjadi kendala tersendiri karena kurangnya pemahaman dalam penyusunan laporan keuangan dan kurang pahamnya atas standar untuk entitas tanpa akuntabilitas public khusunya untuk UMKM tersebut. Penelitian ini didukung dengan hasil dari penelitian yang dilakukan oleh Suhairi (2004) berpendapat bahwa kelemahan UMKM dalam penyusunan laporan keuangan disebabkan rendahnya pendidikan, kurangnya pemahamam terhadap Standar Akuntansi Keuangan (SAK), dan pelatihan penyusunan laporan keuangan. Juga didukung dengan hasil penelitian yang dilakukan oleh Rudiantoro, dan Siregar (2011) yang mengatakan bahwa SAK ETAP bertujuan untuk dapat mengakomodir kebutuhan dari entitas yang tidak memiliki akuntabilitas publik signifikan, dan untuk membantu membuat standar akuntansi yang dapat digunakan oleh UMKM karena sifatnya yang lebih ringkas dan mudah digunakan dibandingkan dengan SAK Umum. Namun yang menjadi hal terpenting dari implementasi SAK ETAP adalah pemahaman yang baik atas SAK ETAP tersebut oleh UMKM tersebut. Para pelaku UMKM memang tidak menganggap penting laporan yang sesuai dengan standar akuntansi yang ada jika usaha mereka masih tergolong mikro. Jangankan menggunakan standar akuntansi, bahkan yang masih belum membuat laporannya pun masih tergolong banyak. Karena memang kebanyakan dari para pelaku UMKM tersebut hanya mengambil mudahnya saja untuk usaha mereka bahkan untuk urusan pencatatan pembukuannya.
Tabel 7

\section{Hasil Penelitian dan Uji Credibility (Triangulasi Sumber dan Triangulasi Teori-Riset Pendukung)}

\begin{tabular}{ccc}
\hline SAK ETAP & Operasionalisasi & $\begin{array}{c}\text { Uji } \\
\text { Credibility }\end{array}$ \\
\hline & -salah satu Standar & \\
& Akuntansi yang & \\
& penggunaanya ditujukan & -informan \\
& untuk entitas usaha yang & HS, HG, IP, \\
& tidak memiliki & K, NQ, dan \\
& akuntabilitas publik, & MM \\
Peperti entitas usaha & - Suhairi \\
SAK ETAP & mikro, kecil dan & $(2004)$ \\
& menengah (UMKM). & - Rudiantoro \\
& -Apabila UMKM & dan Siregar \\
& menerapkan SAK ETAP, & (2011) \\
& maka bank akan lebih & \\
& mudah menyalurkan & \\
& pinjamanya kepada & \\
& UMKM. &
\end{tabular}

Sumber: Data Display dan Data Reduction

\section{Kendala-Kendala Yang Dihadapi oleh Pelaku Usaha Mikro (UMKM) dalam Penyusunan Laporan Keuangan \\ Menurut informan informan tentang kendala-} kendala yang dihadapi dalam penyusunan laporan keuangan usahanya adalah sebagian dari mereka mengatakan bahwa memang menghadapi kendala dalam penyusunannya. Diantaranya kurang pemahaman dalam pengetahuan akuntansi dalam penyusunnya. Seperti penelitian yang dilakukan oleh Suhairi (2004) berpendapat bahwa kelemahan UMKM dalam penyusunan laporan keuangan disebabkan rendahnya pendidikan, kurangnya pemahamam terhadap Standar Akuntansi Keuangan (SAK), dan pelatihan penyusunan laporan keuangan. Pendidikan yang para pelaku usaha memang sangat mempengaruhi dalam kualitas penyusunan laporan keuangan. Semakin baik pendidikan yang dimiliki oleh pelaku usaha mikro maka semakin berkualitas keuangan yang dihasilkan. Sama seperti yang dilakukan oleh peneliti Dian (2009) yang menyimpulkan bahwa pengetahuan akuntansi berpengaruh signifikan terhadap kualitas laporan keuangan, menurut peneliti semakin tinggi tingkat pengetahuan akuntansi, maka semakin baik pula kualitas laporan keuangan yang dihasilkannya.

Selain tingkat pendidikan pelaku usaha mikro yang dianggap menjadi kendala penyusunan laporan keuangan, menurut informan lainnya kendala yang dihadapi adalah karena keterbatasan waktu dan biaya. Waktu, karena para pelaku usaha mikro tidak dengan rutin dalam penyusun laporan keuangan mereka, dan 
masalah biaya karena jika ingin menggunakan jasa ahli untuk menyusun keuangan usahanya, maka mereka akan mengeluarkan biaya lebih untuk itu. Penelitian ini didukung dengan penelitian yang dilakukan oleh Furqan dan Karim( 2012) yang mengatakan bahwa Rendahnya penyelenggaraan dan penggunaan informasi akuntansi dalam pengelolaan UMKM disebabkan oleh persepsi terhadap pentingnya keberadaan informasi akuntansi bagi UMKM, pengetahuan akuntansi pemilik atau karyawan UMKM, pertimbangan biaya-manfaat bagi UMKM dan ukuran UMKM. Dan didukung dengan penelitian Nursetto (2004) Terkait dengan permasalahan keuangan dan pembukuan, para pengusaha UMKM pada umumnya mereka tidak menguasai dan tidak mempraktekkan sistem keuangan yang memadai. Pada umumnya usaha kecil tidak atau belum memiliki pengetahuan dan kemampuan dalam mengelola catatan akuntansi secara ketat dan berdisiplin dengan pembukuan yang teratur, baik dalam bentuk harian, mingguan, bulanan, dan seterusnya, sehingga banyak diantara mereka yang belum memahami pentingnya pencatatan dan pembukuan bagi kelangsungan usaha.

Tabel 8

Hasil Penelitian dan Uji Credibility

(Triangulasi Sumber dan Triangulasi Teori-Riset Pendukung)

\begin{tabular}{|c|c|c|}
\hline $\begin{array}{c}\text { Kendala } \\
\text { Penyusunan } \\
\text { Laporan } \\
\text { Keuangan }\end{array}$ & Operasionalisasi & $\begin{array}{c}\text { Uji } \\
\text { Credibility }\end{array}$ \\
\hline $\begin{array}{l}\text {-Aktor atau } \\
\text { pihak yang } \\
\text { memiliki } \\
\text { kendala } \\
\text { penyusunan }\end{array}$ & $\begin{array}{c}\text {-Para pelaku UMKM } \\
\text { Yang kurang } \\
\text { memahami akuntansi } \\
\text { dan faktor } \\
\text { mendukung kendala } \\
\text { tersebut diantaranya } \\
\text { pendidikan, biaya } \\
\text { dan waktu. }\end{array}$ & $\begin{array}{c}\text {-informan HS, } \\
\text { HG, IP, K, } \\
\text { NQ, dan MM } \\
\text { - Suhairi } \\
\text { (2004) } \\
\text { - Dian (2009) } \\
\text { - Furqan dan } \\
\text { Karim( 2012) } \\
\text { - Nursetto } \\
\text { (2004) }\end{array}$ \\
\hline $\begin{array}{c}\text { - Kendala } \\
\text { pelaku UMKM } \\
\text { dalam } \\
\text { penyusunan } \\
\text { laporan } \\
\text { keuangan }\end{array}$ & $\begin{array}{c}\text {-Tidak menguasai } \\
\text { dan tidak } \\
\text { mempraktekkan } \\
\text { sistem keuangan } \\
\text { yang memadai } \\
\text {-Membuang waktu } \\
\text { dan biaya } \\
\text {-Rendahnya } \\
\text { pendidikan terhadap } \\
\text { pemahaman SAK } \\
\text {-Tidak adanya } \\
\text { peraturan yang } \\
\text { mewajibkan } \\
\text { penyusunan laporan }\end{array}$ & $\begin{array}{l}\text {-Informan HS, } \\
\text { HS, IP, K, } \\
\text { MM, NQ } \\
\text {-Marbun } \\
\text { (1997) } \\
\text {-Suhairi } \\
\text { (2004) } \\
\text {-Jati et.al., } \\
\text { (2009) } \\
\text {-Idrus (2000) } \\
\text {-Pinanti } \\
\text { (2001;2007) } \\
\text {-Furqan dan } \\
\text { Harim (2012) }\end{array}$ \\
\hline
\end{tabular}

$\begin{array}{cc}\text { keuangan bagi } & \text {-Nursetto } \\ \text { UMKM } & (2004) \\ \text {-Keterbatasan } & \text {-Wahyudi } \\ \text { pengetahuan, } & (2009) \\ \text { rumitnya proses } & \text {-Rianto dan } \\ \text { akuntansi } & \text { Siregar (2011) } \\ \text {-Perbedaan } & \\ \text { penerapan akuntansi } & \\ \text { dilihat dari omset } & \\ \text { perusahaan } & \end{array}$

Sumber: Data Display dan Data Reduction

\section{KESIMPULAN DAN SARAN}

Berdasarka penelitian yang dilakukan terhadap persepsi pelaku dan pengetahuan akuntansi pelaku usaha mikro kecil dan menengah (UMKM) atas penyusunan laporan keuangan, didapatkan kesimpulan bahwa dari beberapa pelaku usaha mikro yang menjadi informan kunci peneliti menggunakan pengetahuan akuntansi untuk operasional usaha mereka, namun tidak secara sistematis akuntansi, dan pengetahuan akuntansi mereka hanya sekedar sederhana yang mereka tahu sampai jenjang pendidikan terakhir mereka. Untuk penyusunan laporan keuangan mereka hanya menyusunnya sebatas yang mereka tahu tanpa memisahkan kedalam bentuk-bentuk laporan seperti neraca, laba/rugi, arus kas, posisi keuangan dan catatan atas laporan keuangan. Para pelaku merasa nyaman dengan laporan atau pembukuan sederhana yang mereka buat sendiri. Dan tidak membuatnya secara akuntansi yang biasa dilakukan oleh perusahaanperusahaan atau usaha-usaha besar.

Selain itu para pelaku usaha mikro juga masih belum mengetahui apa itu SAK ETAP, bahkan ada dari mereka yang baru mendengarnya setelah peneliti menanyakan akan hal tersebut. Dan para pelaku usaha mikro juga memiliki kendala yang dihadapai dalam menyusun laporan keuangannya diantaranya adalah karena uang hasil produksi masih tercampur dengan orang kebutuhan rumah tangga, karena pengetahuan tentang akuntansi yang minim dan terbatas membuat mereka terkadang sulit membuat laporan keuangan mereka dan keterbatasan waktu yang biaya. Sehingga baik dari pihak dosen maupun Dinas Koperasi dan Usaha Mikro senantiasa turun tangan membantu para pelaku usaha mikro ini berupa pendampingan, pembinaan dan pelatihan sampai pada tahap pelaporan.

Saran dalam penelitian ini adalah untuk peneliti selanjutnya, bahwa ada banyak kekurangan yang dialami oleh peneliti saat ini, maka diharapkan peneliti selanjutnya dapat beradaptasi di lingkungan objek 
penelitian dan mengetahui cara mendalami pertanyaan sehingga dapat memunculkan pertanyaan-pertanyaan baru. Untuk peneliti selanjutnya, diharapkan memiliki kemampuan komunikasi yang baik, sehingga dapat menggali informasi lebih banyak dari informan.

\section{DAFTAR PUSTAKA}

Afif dan Mulyani. 2016. The Importance of Accounting, Quality of Financial Statements, and Implementation of "Financial Accounting Standards for Entities Without Public Accountability (SAK ETAP)" on SME fostered by PT. Telkom TBK. Journal International Conference of Integrated Microfinance Management. (Online). (https://unpad.ac.id/:, diakses pada tanggal 30 Oktober 2017).

Amoako. 2013. Accounting Practices of SMEs: A Case Study of Kumasi Metropolis in Ghana. International Journal of Business and Management. Vol. 8 No. 24, 2013. (Online). (http://dx.doi.org/10.5539/ijbm.v8n24p73, diakses pada tanggal 30 Oktober 2017).

Emzir. 2012. Metodologi Penelitian Kualitatif Analisis Data. Cetakan ke 3. PT Raja Grafindo Persada. Jakarta.

Ezeagba, Charles. 2017. Financial Reporting in Small and Medium Enterprises (SMEs) in Nigeria. Challenges and Options. Vol. 7 No.1, January $2017 . \quad$ pp.1-10. (Online). (http://dx.doi.org/10.6007/IJARAFMS/v7i1/2534, diakses pada tanggal 28 Oktober 2017).

Farcane, Nicoleta. 2012. Preparation of Financial Statements for Sme's in Romania. Interest for Cash-Flow Statement. Theoretical and Applied Economics. Volume XIX (2012), No. 5(570), pp. 77-92.

Hermawan, Sigit dan Amirullah. 2016. Metode Penelitian Bisnis : Pendekatan Kuantitatif dan Kualitatif. Media Nusa Creative. Malang.

Kurniawanysah. 2016. Penerapan Pencatatan Akuntansi Dan Penyusunan Laporan Keuangan Berdasarkan Sak Etap Pada Umkm Desa Gembongsari Kecamatan Kalipuro Kabupaten Banyuwangi.
Kurniawati dan Arifin. 2012. Penerapan Akuntansi Pada Usaha Mikro Kecil Dan Menengah (UMKM). Journal of Informatics and Business Institute Darmajaya. Vol 10 No. 2, 2012.

Linawati dan Restuti. 2015. Pengetahuan Akuntansi Pelaku Usaha Mikro, Kecil Dan Menengah (Umkm) Atas Penggunaan Informasi Akuntansi.

Mansyur. 2012. Persepsi Pelaku Usaha Mikro Kecil Menengah Atas Penggunaan Laporan Keuangan.

McKinley dan Ellis. 2014. Enterpreneurs Need Accounting Too: The Case For Including Financial And Managerial Accounting In An Entrepreneurship Curriculum.

Memarista, Gesti. 2016. Measuring The Entrepreneur's Financial Knowledge: Evidence From Small Medium Enterprises In Surabaya. Jurnal Manajemen dan Kewirausahaan. Vol. 18 No. 2, 2016. pp 132-144. (Online). (https://scholar.google.co.id/scholar, diakses pada tanggal 29 Oktober 2017).

Nwaigburu. 2013. Impact of Accounting Skills on Entrepreneurship Education for Self-Reliance and Sustainable Development: A Study of Selected Small Scale Business in Owerri Municipal Imo State. Mediterranean Journal of Social Sciences. Vol 4 No 16, 2013.

Urgun dan Ozturk. 2013. Perceptions of Small and Medium Enterprises on IFRS Adaptation Process: a Case Study in Federation of Bosnia and Herzegovina. Journal of Business Administration Research. Vol. 2 No. 1, 2013. (Online). (http://dx.doi.org/10.5430/jbar.v2n1p43, diakses pada tanggal 29 Oktober 2017).

Sari dan Setyawan. 2013. Persepsi Pemilik Dan Pengetahuan Akuntansi Pelaku Usaha Kecil Dan Menengah Atas Penggunaan Informasi Akuntansi.

Svetalekth, Thamrongsak. 2016. Perception Of Accountants Towards The Accounting And Tax Profits From Applying Thai Financial Reporting Standards For Smes 
Setyawati, Hermawan/ 2018 